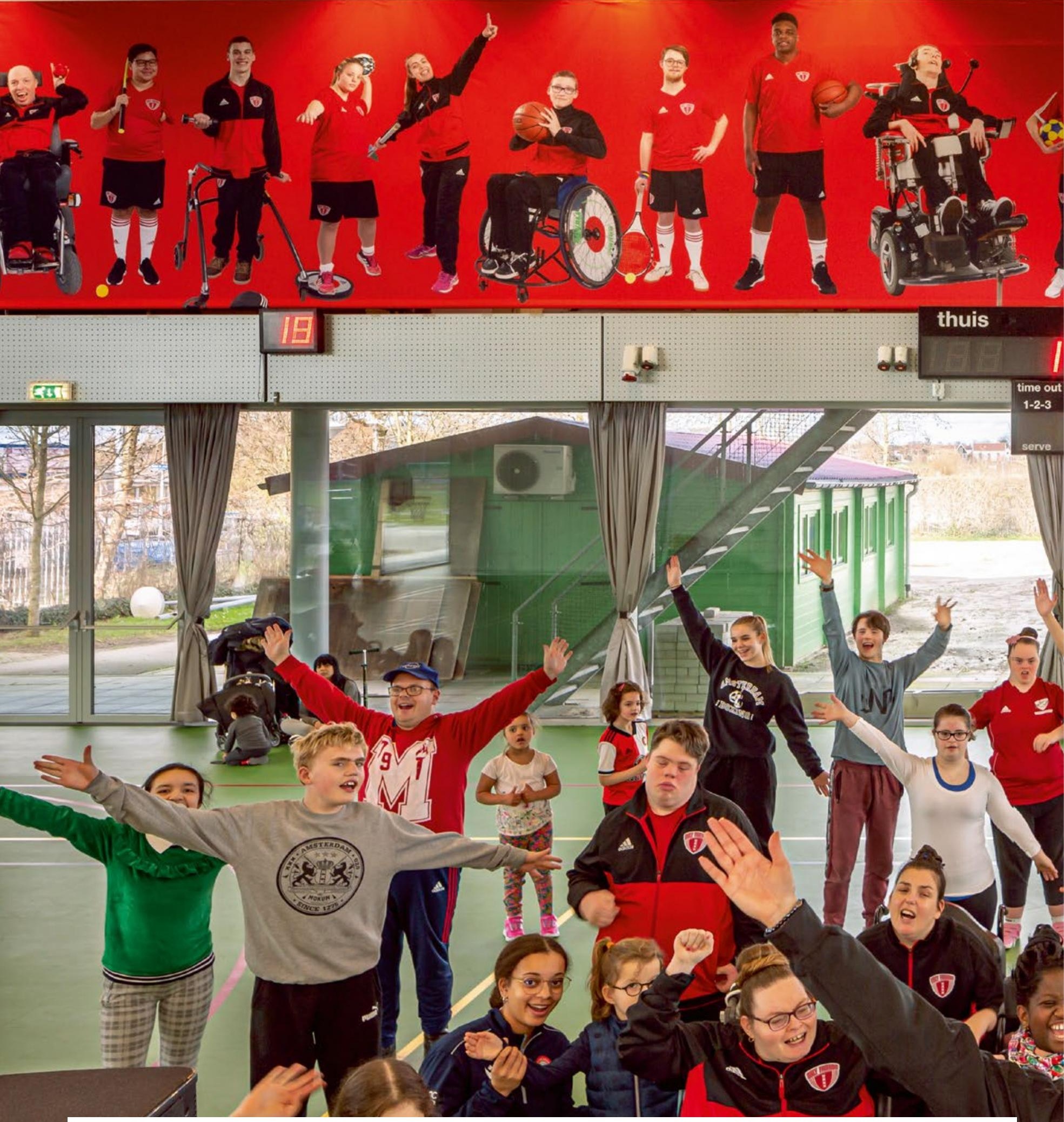

SPORTCLUB ONLY FRIENDS

Het was de laatste bijeenkomst voordat het Coronavirus het openbare leven grotendeels platlegde. In het prachtige Friendship Sports Centre in Amsterdam kon fotograaf Thiis Wolzak nog net de streetdance vastleggen onder leiding van Cynthia Morauw. De volgende dag schortte Only
Friends al haar activiteiten op. Only Friends is een sportclub speciaal bedoeld voor kinderen en jongeren met een lichamelijke of verstandelijke beperking of een chronische ziekte. Ze kunnen deelnemen aan 25 verschillende sporten. Thijs werd meteen goed ontvangen door een meisje dat hem de hand toestak: 'Hallo, ik ben June.' Maar toen hij vanaf een afstandje een jongen met down vroeg of die een stap opzij wilde zetten om mooi op de foto te komen, riep die jongen, goed geïnstrueerd: 'Niet aanraken!' Hopelijk kunnen zij snel weer met elkaar sporten. 


\section{+ Binnenkijken}

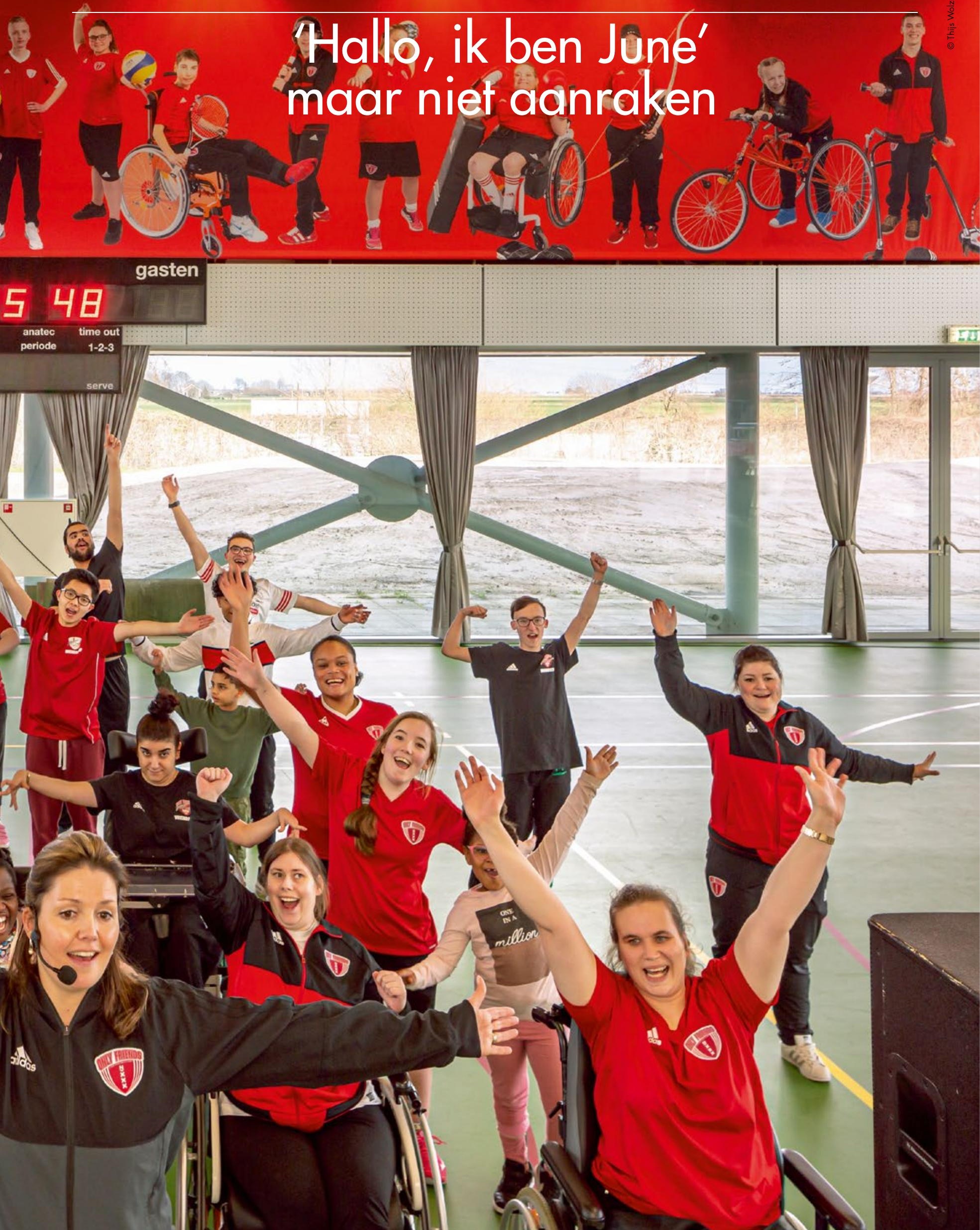

